\title{
Food security and environmental innovation as factors for ensuring sustainable development of regions
}

\author{
Elena Bazhenova*, Irina Musatova, and Elena Zbinyakova \\ Oryol State University named after I. S. Turgenev, 302026 Oryol, st. Komsomolskaya, 95, Russia
}

\begin{abstract}
In modern conditions of the existence of socio-economic systems, the urgent problem is the formation of sustainable development of regions. To study the formation of sustainable development, the authors took two components, such as food security of the region and environmental innovation, an orientation towards a green economy. A comparative analysis of the theoretical aspects of the formation of food security in the works of domestic and foreign scientists is carried out. A study of the Global Food Security Index for 113 countries is presented, using the methods of statistical analysis and analytical grouping, six leading countries in terms of food security are identified. The largest group, accounting for $22.12 \%$ of the total population, is made up of countries in the 71.12-78.21 range of the Food Security Index. The grouping of countries was carried out according to the parameter "Natural resources and sustainability", which showed that the largest group, consisting of 38 countries or $33.62 \%$, is in the range of 44.0-49.9, only 10 countries fell within the borders with the minimum the level of natural resources and sustainability from 32.2 to 38.1 . The analysis made it possible to compile a rating and note the presence of the greatest food security problems in African countries. It is concluded that the transition to environmentally friendly ways of running the economy leads to high productivity of natural resources.
\end{abstract}

\section{Introduction}

Before the period when environmental problems became widespread and obvious, natural resources and ecological well-being were taken for granted and not seen as an advantage.

With the increase in production volumes and the growth of scientific and technological progress, there was a strong anthropogenic impact on the environment, which led to significant disruption of natural processes in terms of energy exchange and an increase in pollution.

Sustainable development of the world's regional systems is based on numerous pillars, among which one can highlight the achievement of Sustainable Development Goal 2 "End

\footnotetext{
* Corresponding author: len.kononowa@yandex.ru
} 
hunger, ensure food security and improve nutrition and promote sustainable agricultural development".

The concepts of sustainable development of a separate territorial unit imply economic prosperity, environmental safety, social security and well-being.

The aim of the study was to assess food security and environmental innovation to achieve sustainable development in the region.

Research objectives:

- to study the existing theoretical studies of the formation of food security in the works of domestic and foreign scientists;

- to analyze the state of food security of world countries, to rank according to the results of the grouping;

- to conduct a comparative analysis of countries with a low level of food security;

- to consider the mechanisms for the formation of sustainable development, taking into account environmental innovations on the example of countries with a low level of food security.

\section{Research methodology}

In the course of writing the article, the methods of a systematic and comprehensive study of sustainable development of regions, methods of statistical analysis, a comparative approach, as well as horizontal and vertical analysis of food security indicators were used. Empirical studies were carried out by the method of analytical grouping by sources of large data sets of the indicator "Global Food Security Index".

\section{Research results}

\subsection{Analysis of the state of food security of world countries}

Sustainable development of world regional systems is based on ensuring food security and improving nutrition for the population of the region of presence. The study analyzed the Global Food Security Index (GFSI) as of 2019 for world countries (access date 1.04.2021).

According to the results of the analysis of the ranking of countries, the following conclusions can be drawn: 113 countries were grouped, the value of the interval is 7,085 , the entire set of countries was divided into 7 groups (Table 1).

- Six countries fall into the group of countries leaders in terms of the Global Food Security Index in the range from 78.21 to 85.3 (the leaders are European countries).

- The largest group consists of 25 countries with an index interval from 71.12 to 78.21 (countries from all continents are present).

- The following groups are also quite numerous, III and IV groups are each represented by 19 countries as well as countries of different continents;

- 15 countries (Myanmar, Guatemala, India, Philippines, Botswana, SriLanka, Nicaragua, GhanaNepal, Mali, Pakistan, Cambodi, Côted'Ivoire, Uzbekistan, Bangladesh) fell within the boundaries with the index level from 49.87 to 56.95 ;

- Countries with a consumption index of less than 50 make up the VI group, which includes 12 countries (Tajikistan, Kenya, Niger, BurkinaFaso, Tanzania, Laos, Senegal, Benin, Togo, Cameroon, Uganda, Venezuela);

- 17 countries of the world are included in the group with a minimum GFSI level from 35.7 to 42.78 (Angola, Congo (Dem. Rep.), Mozambique, Nigeria, Syria, Guinea, Chad, Rwanda, Haiti, Madagascar, Burundi, Ethiopia, and Sierra Leone, Malawi, Zambia, Sudan, Yemen) 
Table 1. Grouping of countries by the Global Food Security Index in 2019

\begin{tabular}{|c|c|c|c|}
\hline $\begin{array}{c}\text { Group } \\
\text { no. }\end{array}$ & $\begin{array}{c}\text { Interval } \\
\text { GFSI }\end{array}$ & $\begin{array}{c}\text { Number of } \\
\text { countries }\end{array}$ & Name of countries \\
\hline $\mathrm{I}$ & $85,3-78,21$ & 6 & $\begin{array}{l}\text { Finland, Ireland, Netherlands, Austria, Czech } \\
\text { Republic, United Kingdom }\end{array}$ \\
\hline II & $78,21-71,12$ & 25 & $\begin{array}{l}\text { Sweden, Israel, Japan, Switzerland, United States, } \\
\text { Canada,Germany, New Zealand, Denmark, Italy, } \\
\text { France, Norway, Portugal, Singapore,Belgium, } \\
\text { Romania, Belarus, Russia, Poland, Spain, Greece, } \\
\text { Costa Rica }\end{array}$ \\
\hline III & $71,12-64,04$ & 19 & $\begin{array}{l}\text { Kazakhstan, Kuwait, Chile, Oman, Hungary, Qatar, } \\
\text { Saudi Arabia, China, Slovakia, Panama, United } \\
\text { Arab Emirates, Malaysia, Bulgaria, Mexico, Peru, } \\
\text { Turkey, Dominican Republic, Bahrain, Brazil }\end{array}$ \\
\hline IV & $64,04-56,95$ & 19 & $\begin{array}{l}\text { Thailand, Serbia, Colombia, Ukraine, Argentina, } \\
\text { Azerbaijan, Morocco, Algeria,Tunisia,Egypt, } \\
\text { Paraguay,Jordan,Vietnam, Bolivia,Indonesia, El } \\
\text { Salvador,Honduras,Ecuador, South Africa }\end{array}$ \\
\hline $\mathrm{V}$ & $56,95-49,87$ & 15 & $\begin{array}{l}\text { Myanmar, Guatemala, India, Philippines, Botswana, } \\
\text { Sri Lanka, Nicaragua, Ghana Nepal, Mali, Pakistan, } \\
\text { Cambodi, Côte d'Ivoire } \\
\text { Uzbekistan, Bangladesh }\end{array}$ \\
\hline VI & $49,87-42,78$ & 12 & $\begin{array}{l}\text { Tajikistan, Kenya, Niger, Burkina Faso, Tanzania, } \\
\text { Laos, Senegal, Benin, Togo, Cameroon, Uganda, } \\
\text { Venezuela }\end{array}$ \\
\hline VII & $42,78-35,70$ & 17 & $\begin{array}{l}\text { Angola, Congo (Dem. Rep.), Mozambique, Nigeria, } \\
\text { Syria, Guinea,Chad, Rwanda, Haiti, Madagascar, } \\
\text { Burundi, Ethiopia,u Sierra Leone } \\
\text { Malawi, Zambia, Sudan, Yemen }\end{array}$ \\
\hline & 113 & & \\
\hline
\end{tabular}

Let us present the grouping results graphically (Figure 1).

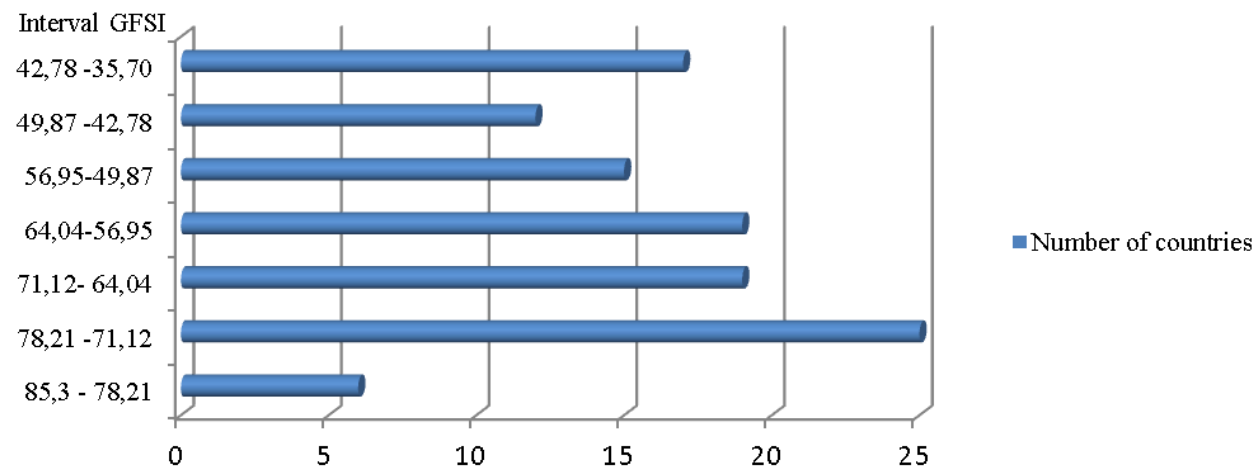

Fig.1. The results of the grouping of countries according to the Global Food Security Index in 2019, the number of countries 


\subsection{Analysis of the state of the indicator "Natural resources and sustainability"}

The Global Food Security Index includes such an indicator as "Natural resources \& Resilience", we will carry out a similar grouping and estimate the number of countries by groups of intervals corresponding to the parameter natural resources and sustainability, the calculated value of the interval is 5.9 (Table 2).

Table 2. Grouping of countries by the parameter «Natural resources \& Resilience» 2019

\begin{tabular}{|c|c|l|l|}
\hline $\begin{array}{c}\text { Group } \\
\text { no. }\end{array}$ & $\begin{array}{c}\text { Interval } \\
\text { GFSI }\end{array}$ & $\begin{array}{c}\text { Number of } \\
\text { countries }\end{array}$ & \multicolumn{1}{|c|}{ Name of countries } \\
\hline I & $73,5-67,6$ & 7 & $\begin{array}{l}\text { Norway, Finland, Ireland, Czech Republic, New } \\
\text { Zealand, Uruguay, Sweden }\end{array}$ \\
\hline II & $67,6-61,7$ & 4 & Costa Rica, Switzerland, Slovakia, Austria \\
\hline III & $61,7-55,8$ & 12 & $\begin{array}{l}\text { Netherlands, United Kingdom, France, Japan, } \\
\text { Spain, Denmark, Romania, Poland, Belarus, } \\
\text { Myanmar, South Korea, Bulgaria }\end{array}$ \\
\hline IV & $55,8-49,9$ & 20 & $\begin{array}{l}\text { Hungary, Colombia, Honduras, Russia, Chile, } \\
\text { Canada, Malaw, Côte d'Ivoire, Panama, } \\
\text { Germany, Greece, Kazakhstan, Sierra Leone, } \\
\text { Niger, Portugal, UnitedStates, China, Italy, } \\
\text { Ukraine,Thailand }\end{array}$ \\
\hline V & $49,9-44,0$ & 38 & $\begin{array}{l}\text { Jordan,Morocco,Nicaragua,Egypt,DominicanRep } \\
\text { ublic,SouthAfrica,Australia,Belgium,Malaysia,Si } \\
\text { ngapore,Turkey,Uzbekistan, Burundi, Angola, } \\
\text { Brazil,Mali,Tunisia,Peru, Zambia, Bolivia, Israel } \\
\text { Sri Lanka, Cameroon, Vietnam, Mexico, Uganda, } \\
\text { Togo, Laos, Kenya, Paraguay, Serbia, Argentina } \\
\text {,Rwanda,Congo (Dem. Rep.), Madagascar, } \\
\text { Sudan,Haiti, Nepal }\end{array}$ \\
\hline VII & $38,1-32,2$ & 10 & $\begin{array}{l}\text { Ecuador, El Salvador, Oman, BurkinaFaso, } \\
\text { Guatemala,Tanzania, Senegal, United Arab } \\
\text { Emirates, Ghana, Pakistan, Algeria,Mozambique } \\
\text { Chad, Syria,Cambodia, Yemen,India,Guinea, } \\
\text { Venezuela,NigeriaBotswanaEthiopia }\end{array}$ \\
\hline VI & $44,0-38,01$ & 22 & $\begin{array}{l}\text { Kuwait,Azerbaijan,Tajikistan,Bangladesh,Philipp } \\
\text { ines,Indonesia } \\
\text { Saudi Arabia,Bahrain,Qatar, Benin }\end{array}$ \\
\hline & 113 & & \\
\hline
\end{tabular}

According to the results of the grouping of countries, the following can be noted:

- 7 countries (Norway, Finland, Ireland, Czech Republic, New Zealand, Uruguay, Sweden) fall into the group of countries leading in terms of natural resources and sustainability in the range from $67.6-73.5$;

- the group II consists of 24 countries with an index interval of 61.7-67.6 (CostaRica, Switzerland, Slovakia, Austria);

- the largest group, consisting of 38 countries or $33.62 \%$, is within the interval 44.0-49.9;

- 22 countries fell within the boundaries with the index level from 38.01 to 44.0, which is $19.46 \%$ of the total number of countries;

- only 10 countries fell within the borders with a minimum level of natural resources and sustainability from 32.2 to 38.1 (Kuwait, Azerbaijan, Tajikistan, Bangladesh, Philippines, 
Indonesia, Saudi Arabia, Bahrain, Qatar, Benin).

As objects of a more detailed study, two countries were selected, which are Kenya and Benin (Table 3).

Table 3. Comparative analysis of indicators of the food security index of Kenya and Benin

\begin{tabular}{|c|c|c|c|}
\hline Food Security Index Indicators & Kenya & & Benin \\
\hline The final GFSI & 49,0 & $>$ & 46,2 \\
\hline 1) AFFORDABILITY & $\mathbf{5 3 , 2}$ & $>$ & 44,2 \\
\hline 1.1) Change in average food costs & 100,0 & $=$ & 100,0 \\
\hline $\begin{array}{l}\text { 1.2) Share of the population below the global } \\
\text { poverty line }\end{array}$ & 28,7 & $>$ & 18,0 \\
\hline 1.3) Income index adjusted for inequality & 34,5 & $>$ & 31,5 \\
\hline 1.4) Import tariffs for agricultural products & 49,4 & $<$ & 60,7 \\
\hline 1.5) Food safety programs & 50,0 & $>$ & 25,7 \\
\hline $\begin{array}{l}\text { 1.6) Market Access and Agricultural Financial } \\
\text { Services }\end{array}$ & 51,5 & $>$ & 30,5 \\
\hline 2) AVAILABILITY & 41,8 & $<$ & 54,8 \\
\hline 2.1) Sufficiency of supplies & 24,2 & $<$ & 62,5 \\
\hline 2.2) Agricultural research and development & 20,6 & $<$ & 30,1 \\
\hline 2.3) Agricultural infrastructure & 25,3 & $<$ & 32,6 \\
\hline 2.4) Agricultural volatility & 70,6 & $<$ & 77,1 \\
\hline 2.5) Political and social barriers to access & 37,2 & $<$ & 53,8 \\
\hline 2.6) Loss of food & 72,3 & $>$ & 58,2 \\
\hline $\begin{array}{l}\text { 2.7) Policy Commitments for Food Security and } \\
\text { Access }\end{array}$ & 50,0 & $=$ & 50,0 \\
\hline 3) QUALITY AND SAFETY & 58,6 & $>$ & 48,3 \\
\hline 3.1) Dietary variety in nutrition & 29,9 & $>$ & 20,9 \\
\hline 3.2) Nutritional Standards & 76,5 & $>$ & 50,0 \\
\hline 3.3) Micronutrient availability & 80,2 & $>$ & 77,3 \\
\hline 3.4) Protein quality & 47,7 & $>$ & 38,6 \\
\hline 3.5) Food safety & 61,7 & $>$ & 49,9 \\
\hline 4) NATURAL RESOURCES \& RESILIENCE & 45,0 & $>$ & 32,2 \\
\hline 4.1) Exposition & 65,2 & $<$ & 66,4 \\
\hline 4.2) Water & 45,0 & $>$ & 0,0 \\
\hline 4.3) Land & 52,8 & $>$ & 34,6 \\
\hline 4.4) Oceans, rivers and lakes & 8,7 & $<$ & 28,2 \\
\hline 4.5) Sensitivity & 72,4 & $>$ & 61,6 \\
\hline 4.6) Political commitment to adaptation & 33,1 & $>$ & 10,8 \\
\hline 4.7) Demographic stress & 27,0 & $>$ & 16,0 \\
\hline
\end{tabular}

The comparative analysis allows us to note that the situation with food security is better in Kenya in three out of four parameters: food availability for the country's population, food quality and security in all parameters, in terms of the sustainability of natural resources, with the exception of water resources (Figure 2). 


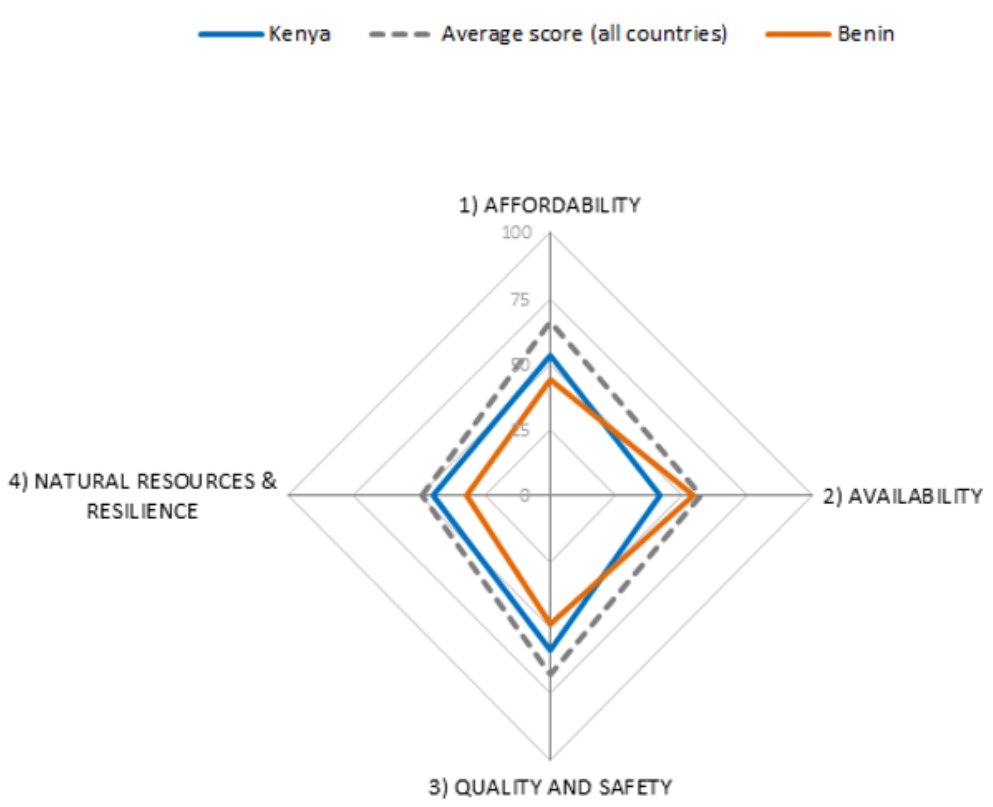

Fig.2. Profile chart of Kenya and Benin according to the 2019 Food Security Index indicators

Thus, Kenya is second to Benin in only one indicator, the availability of agricultural supplies, agricultural development and infrastructure. In Benin, these parameters are at a higher level.

\subsection{Mechanisms for the formation of sustainable development taking into account environmental innovations on the example of countries with a low level of food security}

As the object of the study, the authors chose the country of Kenya, as a predominantly agricultural country, but its economy is different from the economy of many other African countries. The growth of the national economy is closely linked to the growth and development of agriculture. Kenya's GFSI index in 2019 is 49.0.

The most relevant sources of food security problems in Kenya are shown in Figure 3.

- Climate change: Climate change in recent years has been felt mainly by farmers, especially due to dependence on rain-fed agriculture. The changing and unpredictable rainy seasons have greatly affected the ability of farmers to plan their agricultural activities. Due to deforestation, areas that received sufficient rainfall are now receiving insufficient rainfall, reducing the land that can support agriculture. This leads to the need for more intensive use of irrigation agriculture, especially in arid and semi-arid areas. Intensification of irrigation can increase agricultural productivity fourfold and, depending on the crop, incomes can be significantly improved.

Agriculture is the largest source of greenhouse gas emissions in the country ( $1 / 3$ of total emissions), with methane emissions from livestock and land-use changes being the main sources of emissions in this sector. 


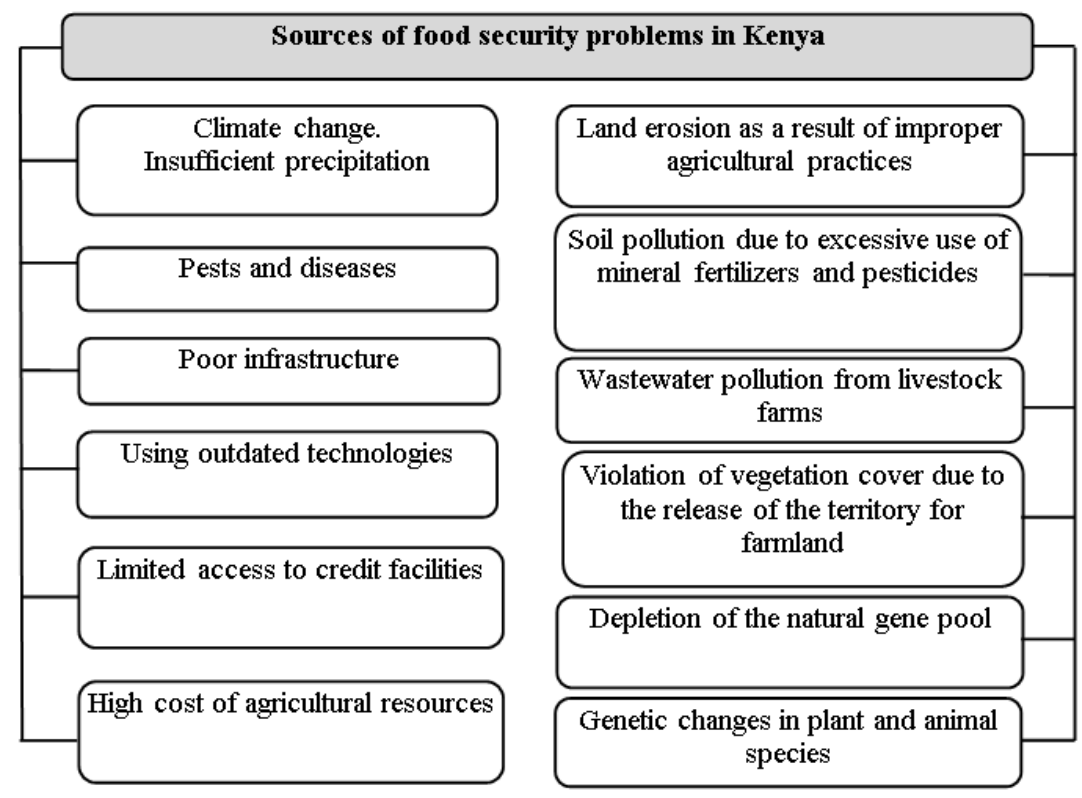

Fig. 3. Sources of food security problems in Kenya

- Pests and diseases cause many losses to farmers in Kenya. This is due to farmers ' lack of information on how to deal with them and diseases that affect food crops, causing significant damage to farmers and threatening food security.

- The use of outdated technologies continues to be a major problem faced by farmers in Kenya. Despite the fact that Kenya has a well-developed system of agricultural research, farmers continue to use outdated and inefficient technologies. This creates a need for extension services that can link research and farmers.

- Developed infrastructure plays a significant role in increasing agricultural productivity in Kenya, as one of the developing economies. Inadequate infrastructure is a significant obstacle to growth and productivity caused by the high transport costs of agricultural resources and products. This also leads to the spoilage of perishable goods during transportation, resulting in large losses for farmers.

- Easy access to and use of credit is one of the main factors influencing the development of small-scale agriculture. Despite numerous financial policies and strategies aimed at providing easy access to credit for small farmers, access to and use of credit continues to be a nightmare for many small farmers in Kenya due to the high interest rates charged on loans, which makes them unattractive. Insufficient financing of agriculture restricts production, investment and value-adding activities in this sector.

- The high cost of agricultural resources has led to an increase in the cost of production, so small farmers are forced to use an expensive farming model, which leads to debt, which makes it expensive for farmers to cultivate on more land.

- Environmental problems, such as land erosion as a result of improper agricultural techniques, soil pollution due to excessive use of mineral fertilizers and pesticides, sewage pollution of livestock farms, violation of vegetation cover due to the release of the territory for farmland.

The mechanisms for implementing climate-optimized agriculture for food security in Kenya are shown in Table 4. 
Table 4. Mechanisms for Implementing Climate Smart Agriculture for Food Security in Kenya

\begin{tabular}{|c|c|}
\hline Title & Goal and directions of the strategy \\
\hline 1 & 2 \\
\hline $\begin{array}{l}\text { The Constitution of Kenya } \\
\text { (2010) }\end{array}$ & $\begin{array}{l}\text { The Constitution promotes sustainable approaches to the } \\
\text { management of natural resources, establishes the right to food } \\
\text { security and to live in a clean and healthy environment, while } \\
\text { emphasizing sustainable and productive land management (for } \\
\text { example, maintaining tree cover on } 10 \text { percent of the country's } \\
\text { territory). }\end{array}$ \\
\hline $\begin{array}{l}\text { Development Strategy } \\
\text { (ASDS 2010-2020) }\end{array}$ & $\begin{array}{l}\text { Provides the foundation for transforming agriculture into a modern } \\
\text { and commercially viable sector. The current plan focuses on } \\
\text { addressing issues such as food security and nutrition, over-reliance } \\
\text { on rain-fed agriculture, youth unemployment, poverty reduction } \\
\text { and the high cost of resources. The strategy states that adaptation to } \\
\text { climate change is a priority for the country. }\end{array}$ \\
\hline $\begin{array}{l}\text { Kenya Development Plan } \\
\text { (Vision 2030) - Outlook for } \\
2030(2008-2030)\end{array}$ & $\begin{array}{l}\text { It is the country's development plan for } 2008-2030 \text {, which } \\
\text { identifies agriculture as a key sector for stimulating economic } \\
\text { growth. It aims to transform small-scale agriculture from a low- } \\
\text { productivity subsistence activity to an innovative, competitive } \\
\text { agricultural sector. Operating under a series of five-year medium- } \\
\text { term plans, the current five-year medium-term plan focuses on } \\
\text { devolution, socio-economic development, equality and national } \\
\text { unity. }\end{array}$ \\
\hline $\begin{array}{l}\text { Medium-term Investment } \\
\text { Plan for the Agricultural } \\
\text { sector }(2010)\end{array}$ & $\begin{array}{l}\text { The goal is to increase productivity in key subsectors through } \\
\text { targeted investment. Major climate-related issues are addressed, } \\
\text { including early warning systems and climate change adaptation } \\
\text { measures, as well as the differentiation of investments based on } \\
\text { high rainfall, semi-arid and dry areas. }\end{array}$ \\
\hline $\begin{array}{ll}\text { National Climate } & \text { Change } \\
\text { Response } & \text { Strategy } \\
\text { (NCCRS) (2010) } & \end{array}$ & $\begin{array}{l}\text { Adaptation measures proposed for agriculture in the NCCRS } \\
\text { include land-use changes, restoration of degraded ecosystems, } \\
\text { provision of reduced meteorological information and agricultural } \\
\text { resources, collection of water for irrigation, protection of the } \\
\text { natural resource base (soil and water conservation methods), } \\
\text { research and distribution of excellent (drought-tolerant, salt- } \\
\text { tolerant, pest-and disease-resistant) crops }\end{array}$ \\
\hline $\begin{array}{l}\text { National Action Plan on } \\
\text { Climate Change (NCCAP) } \\
(2013-2017)\end{array}$ & $\begin{array}{l}\text { Within this framework, Kenya plans to develop a low-carbon } \\
\text { National Mitigation Plan for energy, transport, industry, } \\
\text { agriculture, forestry and waste management. Selected mitigation } \\
\text { methods under NCCAP included reforestation on degraded land, } \\
\text { agroforestry, increasing tree cover to } 10 \text { percent of the total land } \\
\text { area, and conservation tillage. }\end{array}$ \\
\hline $\begin{array}{l}\text { Session document No. } 3 \text { of } \\
2009 \text { "On National land } \\
\text { policy» }\end{array}$ & $\begin{array}{l}\text { Encourages the sustainable intensification of land use in high- } \\
\text { potential, densely populated areas by applying effective methods, } \\
\text { improving the condition and productivity of degraded land, and by } \\
\text { applying cost-effective irrigation methods. }\end{array}$ \\
\hline $\begin{array}{l}\text { The Farm Forestry } \\
\text { Regulations (2009) }\end{array}$ & $\begin{array}{l}\text { It sets out the requirements for farmers to establish and maintain } \\
\text { farm forestry (i.e. forest plots) on at least } 10 \text { percent of all } \\
\text { agricultural land. In addition, the planted tree species or varieties } \\
\text { should not adversely affect water sources, crops, livestock, soil } \\
\text { fertility and the surrounding area, and should not be invasive. In } \\
\text { addition, agricultural authorities at the district (now county) level } \\
\text { are required to identify land at risk of degradation and take the } \\
\text { necessary measures to ensure its conservation, including tree }\end{array}$ \\
\hline
\end{tabular}




\begin{tabular}{|l|l|}
\hline $\begin{array}{l}\text { Draft National Irrigation } \\
\text { Policy (2014) }\end{array}$ & $\begin{array}{l}\text { The objectives of this policy are to expand irrigated land, increase } \\
\text { agricultural capacity for water collection and storage, promote } \\
\text { water collection, use of wastewater, and use of groundwater for } \\
\text { irrigation; build capacity for the production and use of irrigation } \\
\text { research, innovation, and technology; and promote and adopt an } \\
\text { integrated approach to sustainable commercial irrigation farming. }\end{array}$ \\
\hline $\begin{array}{l}\text { National Agricultural } \\
\text { Research System Policy } \\
\text { (2012) }\end{array}$ & $\begin{array}{l}\text { The policy aims to establish an integrated national agricultural } \\
\text { research system that guides and supports the development of an } \\
\text { innovative, commercially oriented and modern agricultural sector; } \\
\text { develop a new agricultural research funding mechanism that } \\
\text { ensures the adequacy, predictability and sustainability of research; } \\
\text { and develop a comprehensive framework for partnerships and } \\
\text { consultation, as well as cooperation with stakeholders. }\end{array}$ \\
\hline $\begin{array}{l}\text { CAADP (treaty on a } \\
\text { comprehensive programme } \\
\text { for the development of } \\
\text { agriculture in Africa) } \\
\text { (2015) }\end{array}$ & $\begin{array}{l}\text { The Kenya CAADP Treaty commits the government to implement } \\
\text { the overall sector vision outlined in the Agricultural Sector } \\
\text { Development Strategy (ASDS) to address the country's agricultural } \\
\text { development agenda. }\end{array}$ \\
\hline $\begin{array}{l}\text { National Program for the } \\
\text { Rational Use of Climate in } \\
\text { Agriculture (2015) }\end{array}$ & $\begin{array}{l}\text { The goal of the program is to build sustainable agriculture to } \\
\text { climate change and low-carbon growth. }\end{array}$ \\
\hline $\begin{array}{l}\text { Draft National Forest policy } \\
\text { (2015) }\end{array}$ & $\begin{array}{l}\text { The goal is the conservation and sustainable development of forest } \\
\text { resources for present and future generations. }\end{array}$ \\
\hline
\end{tabular}

By 2030, the Kenyan economy plans to adapt to climate change. The Government of Kenya and the UN Environment Division believe that the transition to the use of lowemission resources of the "green" economy will lead to strong economic growth and increased opportunities for creating national wealth by 2021. The report, "The country's Aggregate Greenhouse Gas Emissions," details the economy's "green" measures that are designed to mitigate the impact of climate change. As a result of the new economic scenario, the concentration of carbon dioxide will be reduced by $9 \%$ by 2030 . In the agricultural sector, the implementation of the Green Economy investment plan will lead to an increase in the average agricultural yield of approximately $15 \%$, relative to its current baseline. Agriculture has accounted for approximately a quarter of Kenya's annual GDP and up to $65 \%$ of exports in recent years.

The transition to a "green" economy can save the state budget approximately 45 million US dollars by 2030. In addition to significant cost savings, the transition to environmentally friendly ways of doing business brings other benefits: food security, a clean environment and high productivity of natural resources.

In Kenya, extensive measures are planned to apply environmental innovations. In the future, energy generation will be entrusted to eco-friendly windmills and solar panels, and they will help save money that farms now use to pay for electricity and heat.

\section{The discussion of the results}

The study of the issues of sustainable development of regions and ensuring food security of the country is one of the most important areas, which has received considerable attention in the economic literature. This is explained by the strategic importance of the analyzed issues, since it is the presence of food security that is a condition for achieving socio-economic stability in society. 
Boldyreva I.A., Andryushchenko O.G., Nikitaeva A.Yu., Udalova Z.V. [1] in their studies analyze the factors affecting the food security of the country, and note food security as an essential element of the economic security of the state.

Authors Kovalenko E.G., Polushkina T.M., Yakimova O.Yu. [2] believe that one of the factors of food security is the sustainable development of rural areas.

Krasnoperova E.A., Donnik I.M., Yuldashbaev Yu.A., Leshcheva M.G., Kulakov V.N. [3] study the dependence of agricultural development and food security on the example of Russia.

L. Kalinina, I. Zelenskaya, O. Vlasenko were involved in the development of an approach that would allow a comprehensive assessment of the food supply of the country's regions, determine the regional capabilities and determine priorities in the development and adjustment of programs for the socio-economic development of regions and product markets $[4] /$

The results of studies by Vysochina A., Stoyanets N., Olezharts T. [5] showed that the food security of the country in the short term is influenced by environmental factors: a decrease in carbon dioxide emissions, electrification of the rural population, access to clean fuels, production of renewable energy, arable land.

Such authors as L. Rudneva, I. Pchelintseva, M. Gureva [6] pay attention to the development of a green economy and the theory of environmental innovation. These researchers note that for sustainable development, it is necessary for businesses to raise corporate social responsibility, develop green technologies and promote a green economy.

The analysis of theoretical prerequisites for the necessity and effectiveness of the environmental component of corporate social responsibility was carried out by Grazhevskaya N., Mostepanyuk A. [7]. The authors highlight the distinctive features of four approaches of corporate social responsibility in order to build a holistic view of the evolution of understanding the role of nature in the context of achieving long-term goals of business and humanity as a whole.

Scarpellini S., Valero-Gil J., Moneva J. M., Andrea M. [8] in their studies consider as a form of rational environmental management, a cyclical economy, which is based on completely new models of production and consumption.

The works of Durmanov A, Bartosova V., Drobyazko S., Melnik O., Fillipova V. [9] are devoted to the issues of ensuring sustainable development of enterprises in the information space. The analysis of the need for an evolutionary transition to a "green economy" is substantiated by A.V. Kravchenko. [10], I.R. Lyapina, I.V. Skobliakova, M.A. Vlasova, T.L. Lukyanchikova, E.E. Kononova [11].

The development of a green economy in Russia, the need to invest in "green", "digital", "smart" technologies are devoted to the works of Tarkhanova E.A., Chizhevskaya E.L., Frickler A.V., Baburina N.A., Firtseva S.V. [12].

\section{Conclusions}

Achieving sustainable development is relevant for all countries in connection with the existing problems of the modern world. This work focused on food security as a factor in achieving sustainable development of countries. The studies carried out allow us to note that food security depends on external and internal threats, directly affects the security of the state.

In turn, the food security of the country in the short term is influenced by many environmental factors, the state of natural resources, the so-called "natural sustainability". It is noted that one of the models of rational use of natural resources is a circular economy with elements of environmental innovation. 
The analysis of the Global Food Security Index on the example of 113 countries made it possible to rank according to the presented analytical group, during which 6 European countries leaders were identified in terms of the highest level of food security, within 78.21-85.3. These are countries such as Finland, Ireland, Netherlands, Austria, Czech Republic, United Kingdom. The largest group, constituting $22.12 \%$ of the total population, are countries in the range $71.12-78.21$ of the Food Security Index

The analysis of the "Natural resources \& Resilience" parameter revealed a large group, consisting of 38 countries, constituting $33.62 \%$ of the total population within the interval 44.0-49.9. Ten countries fell within the borders with the minimum level of natural resources and sustainability. It was revealed that the minimum consumption index is present in African countries.

Mechanisms for the formation of sustainable development, based on government programs and strategic development plans, taking into account programs aimed at combating climate change, supported by environmental innovations, are most effective in solving the problem of food security. The use of environmental innovations makes it possible to increase yields, save water resources in comparison with traditional farming methods. Green innovation harnesses clean and affordable solar energy and offers a significant opportunity to improve food security and accelerate economic growth.

\section{References}

1. A. Boldyreva, O. G. Andryushchenko, A. Y. Nikitaeva, Z. V.Udalova, J. Rudash, Journal of environmental management and tourism, 4, 20 (2017)

2. E.G. Kovalenko, T.M. Polushkina, O.Y. Yakimova, Asian Social Science. 8, 181 (2015)

3. E.A. Krasnoperova, I.M. Donnik, Yu.A. Yuldashbaev, M.G. Leshcheva, V.N. Kulakov, S.O. Chylbak-ool, Bulletin of the National Academy of Sciences of the Republic of Kazakhstan. 6, 388 (2020)

4. L. Kalinina, I. Zelenskaya, O. Vlasenko, Smart innovation, systems and technologies, 172, 731 (2020)

5. A. Vysochyna, N. Stoyanets, G. Mentel, T. Olejarz, Sustainability, 10, 4090 (2020)

6. L. Rudneva, I. Pchelintseva, M. Gureva, Scenario modelling of the "green" economy in an economic space. Resources, 2, 7 (2018)

7. N. Grazhevska, A. Mostepaniuk, Ecological components of corporate social responsibility: theoretical background and practical implementation. Journal of environmental management and tourism, 5, 1060-1067 (2020)

8. S. Scarpellini, J. Valero-Gil, J.M.Moneva, M. Andreaus, Business Strategy and the Environment, 29, 1 (2020)

9. A. Durmanov, V. Bartosova, S. Drobyazko, O. Melnyk, V. Fillipov, Journal of Entrepreneurship and Sustainability Issues, 7, 1377-1386 (2019).

10. A.V. Kravchenko, Innovation and investment, 2, 24-26 (2021)

11. I.R. Lyapina, I.V. Skobliakova, M.A. Vlasova, T.L. Lukyanchikova, E.E. Kononova, Advances in Intelligent Systems and Computing, 726, 748-757 (2019)

12. E.A. Tarkhanova, E.L. Chizhevskaya, A.V. Fricler, N.A. Baburina, S.V. Firtseva, Entrepreneurship and Sustainability Issues, 8, 649-661 (2020) 